Review Article

\title{
COMPARATIVE ANALYSIS OF THE NUMBER OF SHEEP IN FYR AND SOME EUROPEAN COUNTRIES ${ }^{1}$
}

\author{
Slavica Arsič², Marijana Jovanovičc ${ }^{3}$, Zorica Sredojevic ${ }^{4}$
}

\begin{abstract}
Summary
Sheep farming in Serbia, from year to year, notices a descending course in number of sheep, as well as in production of milk and meat. The main objective of this paper is the analysis of the number of sheep in Serbia and the surrounding countries (FYR).

By comparing the current state of the total number of sheep (in 2011) with the state in the former Yugoslavia, the result shown is that there are 66\% less sheep in Serbia compared to the total number seen in 1967 (base year). Compared to the last census from 2012, there is an increased number of sheep in Serbia, compared to previous year (2011) by 18.4\%.

Other former Yugoslav republics (FYR) also have a decrease in the total number of sheep: in Bosnia and Herzegovina by 76.5\%, in Montenegro by 64.3\%, in Croatia by 41.3\%, in Macedonia by 63.5\% compared to 1967 (base year), except for Slovenia, which has an increase in the total number of sheep by 83,000 head of cattle.
\end{abstract}

In paper is given overview of the number of sheep for some European countries and for some part of world, in purpose of comparison with sheep state in FYR.

Key words: sheep, former Yugoslavian republics (FYR), Europe, world.

JEL: $Q 10, Q 19, P 50$

1 Paper is part of the research projects: III-46006 - Sustainable agriculture and rural development accomplishing the strategic objectives of the Republic of Serbia within the Danube region; 46009 - Promotion and development of hygienic and technological processes in the production of foods of animal origin in order to obtain high-quality and safe products competitive on the world market; and 179028 - Rural labour markets and rural economy of Serbia - the diversification of income and poverty reduction, funded by the Ministry of Education, Science and Technological Development of the Republic of Serbia for the period 2011-2015.

2 Slavica Arsić, M.A., Research Assistant, Institute of Agricultural Economics, Volgina Street no. 15, 11060 Belgrade, Serbia, Phone: + 381116972 852, E-mail: slavica a@iep.bg.ac.rs

3 Marijana Jovanović, B.Sc., Research Assistant, Institute of Agricultural Economics, Volgina Street no. 15, 11060 Belgrade, Serbia, Phone: +381 1169 72 842, E-mail: marijana j@iep.bg.ac.rs

4 Zorica Sredojević, Ph.D., Full Professor, University of Belgrade, Faculty of Agriculture, Institute for agroeconomy, Nemanjina Street no. 6, 11080 Zemun, Serbia, Phone: +381 112615 315/int 297, E-mail: zokas@agrif.bg.ac.rs

EP 2015 (62) 2 (453-466) 


\section{Introduction}

Regional sheep breeds are important for the social and economic structure of rural communities in their locality, and local knowledge of livestock is recognized as an essential contributor to both economic and environmental sustainability (Tempelman, Cardellino, 2007). Regional sheep breeds have evolved in and have become adapted to their environments, often thriving under extreme and stressful conditions. These breeds may therefore have unique characteristics providing a valuable resource of genetic variation. This variation is essential both to develop sustainable animal production systems and to mitigate against unpredictable future events. Unlike goat breeding, which has been prohibited on the territory of exYugoslavia since 1948, when the Law on goat breeding prohibition (except for white goats, whose breeding was allowed under certain conditions) was passed, due to damages they caused in forest areas; sheep breeding has been allowed on the entire territory of ex-SFRY (Cecić et al., 2007). Because of that, sheep breeding was one of the basic sources of the population existence in hilly-mountain areas until the mid-sixties of the XX century.

The capability of sheep to live and reproduce on soil not suitable for other types of agricultural production makes this species of domestic animals significant in world and Serbian agriculture. They are typical pasture animals, as they can spend 7-8 months a year on pastures. Seventy percent of nutrients they need, they get from quality grazing, which is important in terms of cost-effectiveness in their breeding. In the developed countries, growers are especially encouraged to keep their sheep on pastures, and in that way contribute to the ecosystem preservation and prevention of the development of weeds. Also, one shouldn't forget that ruminants (sheep) exploit bulky food very well, which can be produced in large quantities in crop production and which can be very different, starting with those that are produced specially, to those that are obtained as by-products of crop production and processing (Arsić et al., 2013).

Sheep breeding is very profitable, because investment is low and the products of it are highly valued and sought after in the market (Sredojević, Popović, 2014).

Native breeds of farm animals represent an important resource, from the perspective of their genetics and their contributions to environmental and economic sustainability (Ruane, 2000). Native livestock breeds play a central role in low input extensive farming systems and in supporting rural communities in both the developed and developing nations of the world (Drucker et al., 2001). No matter what we possess in natural resources and tradition, sheep breeding in Serbia, in terms of productivity, occupies an undesirable position.

The largest part the population of our sheep makes pramenka $(80 \%)$ of which the most common strains in Serbia are: pirot, sjenica and svrljiška, while the remaining $20 \%$ are cigaja (5\%) and crossbreeds of pramenka with foreign races (15\%), primarily with virtenberg and ill d' France. Sheep production holds the fourth place in the 
Serbian livestock by head, with an average number of $1.5-1.6$ million heads (Arsić et al., 2012).

According to the last census from 2012 in the Republic of Serbia, out of the total number of sheep, 1,712,036 heads of sheep are located at family households (99\%) and only 17,242 animals are in commercial companies and cooperatives, representing just $1 \%$.

The biggest grower of sheep in the world is China, which based on FAO data has 136 million sheep. The number of sheep, by continents for 2009, was: Africa: 297.12 million; Asia: 452.6 million; Australia: 105.12 million (only Australia and New Zealand - without other parts of Oceania); Europe: 131.2 million; South America: 72.4 million (without some parts of Middle America) and North America: 65.7 million (without some parts of Middle America). The total number of sheep estimated in the world is 1.08 billion (FAO, 2009).

\section{Material and Method}

The paper will present an analysis of the state of the total number of sheep in Serbia and other former Yugoslav republics, as well as the movement of the total number of sheep in the European countries with the highest percentage of sheep heads. Comparative analysis will be focused on the movement of the total sheep every ten years in the forty-five years period at the situation in the former Yugoslavia, with the following taken as base years: 1967, 1977, 1987, 1997, and 2007, as well as movement of sheep numbers in a continuous period from 2007 to 2011.

There will also be calculated a percentage of the number of sheep in individual Republics of the former Yugoslavia as well as their numerical strength to the surface of the land, the total agricultural area, numbers of sheep in the state compared to 1,000 inhabitants, and their share in the total number of sheep in Europe and in world production.

The main data sources used to achieve the stated goals were published in the following statistical yearbooks: Statistical Yearbook of Serbia, Croatia, Slovenia, Bosnia, Montenegro and Macedonia. From these publications stem the statistically analyzed data for a certain year. In addition, we have used the published material from relevant institutions from Serbia, data from the Food and Agriculture Organization (FAO) and numerous scientific and professional publications. The collected data is presented through tables and graphs analyzed by standard mathematical methods.

\section{Results and Discussion}

\section{The movement of the total number of sheep in Serbia and FYR}

From 1931 to 1968, with some fluctuations, the number of sheep in Yugoslavia generally held about 10-11 million head. In the sixties, former Yugoslavia occupied the fourth place in Europe in sheep breeding, behind the UK, Spain and Romania, because Serbia 
had 4.3 to 4.8 million heads of sheep. As for the other Yugoslav republics during the period of the sixties (in 1967), total number of sheep was moving in Macedonia and Bosnia and Herzegovina from 2 to 2.2 million heads; Croatia around $1-1.1$ million head; Montenegro 600 thousand and 37 thousand sheep in Slovenia (FSO, 1968).

In the seventies (1977), total number of sheep was: Serbia 2,733 thousand head of sheep, which is $36.4 \%$ less compared to 1967. As for the rest of the Republics: in Bosnia there were 1,523 thousand or 31.1\% less sheep; in Macedonia 1,865 thousand or $11.3 \%$ less; in Croatia 801 thousand sheep - a decrease by $26.5 \%$; in Montenegro 547 thousand head of sheep less, which is lower by $6.4 \%$ and in Slovenia 15 thousand head of sheep less, where for 10 years there has been the greatest decrease in the total number of sheep by about $60 \%$ compared to in 1967 (FSO, 1977).

In the eighties (1987) there also occurs a decrease in the total number of sheep in Serbia and all the Yugoslav republics when the fund of sheep almost halved in comparison to 1967. Compared to in 1977, there are smaller fluctuations in the decline of the total number of sheep: in Serbia by $1.3 \%$; in Bosnia and Herzegovina by $6 \%$; in Montenegro by $10.2 \%$; in Croatia by $9.9 \%$. However, in Macedonia and Slovenia there is an increase in sheep heads: for Macedonia that increases is $34.2 \%$ and $66.6 \%$ for Slovenia (FSO, 1988).

If we compare 1997 to 1987 , we get a result that shows that decrease in total sheep number in Serbia is 21.2\%; in Bosnia and Herzegovina we find the greatest decrease in sheep heads (83.5\%); in Montenegro by $10.2 \%$; in Croatia by $37.3 \%$; in Slovenia by $8 \%$ and in Macedonia by 47.5\% (SORS, 1998; FSO, 1988; SURS, 2013; FOS, 2011; SBC, 2012a, 2012b; MONSTAT, 2011; SSORM, 2012).

The trend of decreasing continues with bigger or smaller fluctuations in the nineties until 2000 when Serbia had 1,611 thousand heads of sheep. In the other former Yugoslav republics, the total numbers of sheep in 2000 were: in Croatia 528,000 sheep heads; in Bosnia and Herzegovina 311,206 sheep heads; in Montenegro 306 thousand; in Macedonia 1,251 thousand and in Slovenia 98,227 sheep heads. Slovenia had the biggest increase of sheep heads in 2000 compared to the previous year (1999), when it had a little bit over 40 thousand sheep. However, if we compare the total number of sheep in the ten-year period (1997-2007), the decrease in the number of sheep in Serbia was by $24.5 \%$; in Montenegro by $49.4 \%$ and in Macedonia by $37.8 \%$. The biggest increase is in Slovenia by 108,180 head of sheep, followed by Bosnia and Herzegovina with $131 \%$ or 312,490 head of sheep and Croatia by $42.6 \%$ or by 193 thousand heads of sheep (Table 1). 
Table 1. The number of sheep in Serbia and the former Yugoslav Republic

\begin{tabular}{|c|r|r|r|r|r|r|r|}
\hline \multicolumn{7}{|c|}{ Total number of sheep (in 000 heads) } \\
\hline Year & Serbia & $\begin{array}{c}\text { Bosnia and } \\
\text { Herzegovina }\end{array}$ & Montenegro & Croatia & Slovenia & Macedonia & SFRY* \\
\hline 1967 & 4,307 & 2,211 & 584 & 1.089 & 37 & 2,101 & 10,329 \\
\hline 1977 & 2,733 & 1,523 & 547 & 801 & 15 & 1,865 & 7,484 \\
\hline 1987 & 2,698 & 1,432 & 489 & 722 & 25 & 2,503 & 7,869 \\
\hline 1997 & 2,127 & 237 & 439 & 453 & 23 & 1,315 & 4,594 \\
\hline 2000 & 1,611 & 311 & 306 & 528 & 96 & 1,251 & 4,103 \\
\hline 2007 & 1,606 & 549 & 222 & 646 & 131 & 817 & 3,971 \\
\hline 2008 & 1,605 & 533 & 209 & 643 & 138 & 816 & 3,944 \\
\hline 2009 & 1,504 & 534 & 199 & 619 & 138 & 755 & 3,749 \\
\hline 2010 & 1,475 & 519 & 198 & 630 & 130 & 778 & 3,730 \\
\hline 2011 & 1,460 & 519 & 208 & 639 & 120 & 767 & 3,713 \\
\hline $\begin{array}{c}\text { Average } \\
2007- \\
2011\end{array}$ & $\mathbf{1 , 5 3 0}$ & $\mathbf{5 3 0 . 8}$ & $\mathbf{2 0 7 . 2}$ & $\mathbf{6 3 5 . 4}$ & $\mathbf{1 3 1 . 4}$ & $\mathbf{7 8 6 . 6}$ & $\mathbf{3 , 8 3 0 . 4}$ \\
\hline
\end{tabular}

Source: FSO, 1968, 1978, 1988; SORS, 1998, 2001; SURS, 2013; FOS, 2011; SORS, 2014; SBC, 2012a, 2012b; MONSTAT, 2011; SSORM, 2012.

Note: * Since 1991 SFRY have not existed, so calculation from 1997 - 2011 represents sum of individual republics of former SFRY.

In 2007 (compared to 2000), there is an increase in Slovenia by 36.3\%; in Bosnia and Herzegovina by $22.3 \%$. As for other republics, there is a reduction of the total number of sheep, so that the largest decrease is in Macedonia in 2007, compared to 2000 by 34.7\%; in Montenegro by $12.8 \%$; while in Serbia it is lowest at $0.3 \%$. In Serbia in 2006, there were $3.4 \%$ less sheep compared to 2000. However, in 2007, there was an increase compared to 2006, by 3.2\% (SORS, 2012).

Continuous movement of sheep number in Serbia, the surroundings and the world

If 2007 is taken as the base year for the period until 2012, we get results that indicate that in 2008 there is the greatest decrease in the total number of sheep: in Montenegro $(5.8 \%)$ and in Bosnia and Herzegovina (3\%), while in Macedonia, Serbia and Croatia, the reduction was minimal and ranged from 0.1 to $0.5 \%$. The largest increase in the total number of sheep in 2008 (compared to 2007) is recorded in Slovenia and it amounts 5.9\%.

In 2009 in comparison with 2007 an increase exists only in Slovenia (5.3\%), while in the other former Republics there is a noticeable decrease in the total number of sheep: in Montenegro by $10.11 \%$, in Macedonia by $7.6 \%$, in Serbia by $6.4 \%$; in Croatia by $4.2 \%$ and in Bosnia and Herzegovina by $2.8 \%$

The total sheep number in 2010, compared to 2007: in all Republics, there is a noticeable trend of decreasing, which is the highest in Montenegro at $10.1 \%$, in Serbia by $8.2 \%$; then in Bosnia and Herzegovina by $5.5 \%$, in Macedonia by $4.8 \%$; in Croatia by $2.5 \%$. Only in Slovenia is the total number of sheep reduced by $0.9 \%$, as the lowest rate. 
In 2011, the total number of sheep in Serbia and the former Yugoslav republics calculated in relation to the base year (2007) points out a decrease in total number of sheep in all republics in last four years. In Serbia, the decrease is the highest (9.1\%), followed by Slovenia with $8.5 \%, 6.2 \%$ in Macedonia, Montenegro with 6.1\%, 5.4\% in Bosnia and Herzegovina, while the lowest percentage of decrease in heads of sheep is in Croatia, $1.1 \%$.

Table 2. The percentage share of individual Republics in total sum of sheep FYR (in \%)

\begin{tabular}{|c|c|c|c|c|c|c|}
\hline \multicolumn{7}{|c|}{ Total number of sheep of all Republics (in \%) } \\
\hline Year & Serbia & $\begin{array}{c}\text { Bosnia and } \\
\text { Herzegovina }\end{array}$ & Montenegro & Croatia & Slovenia & Macedonia \\
\hline 1967 & 41.7 & 21.4 & 5.7 & 10.5 & 0.4 & 20.3 \\
\hline 1977 & 36.5 & 20.3 & 7.3 & 10.7 & 0.2 & 25.0 \\
\hline 1987 & 34.3 & 18.2 & 6.2 & 9.2 & 0.3 & 31.8 \\
\hline 1997 & 46.3 & 5.2 & 9.5 & 9.9 & 0.5 & 28.6 \\
\hline 2000 & 39.3 & 7.6 & 7.4 & 12.9 & 2.3 & 30.5 \\
\hline 2007 & 40.4 & 13.8 & 5.6 & 16.3 & 3.3 & 20.6 \\
\hline 2008 & 40.7 & 13.5 & 5.3 & 16.3 & 3.5 & 20.7 \\
\hline 2009 & 40.1 & 14.3 & 5.3 & 16.5 & 3.7 & 20.1 \\
\hline 2010 & 39.5 & 13.9 & 5.3 & 16.9 & 3.5 & 20.9 \\
\hline 2011 & 39.3 & 14.0 & 5.6 & 17.2 & 3.2 & 20.7 \\
\hline
\end{tabular}

Source: FSO, 1968, 1978, 1988; SORS, 1998, 2001; SURS, 2013; FOS, 2011; SORS, 2014; SBC, 2012a, 2012b; MONSTAT, 2011; SSORM, 2012.

The share percentage of sheep number for certain republics in the total number of all republics is shown in Table 2. According to given calculation, in each year, Serbia has the largest share in the total number of sheep. If we look at the period of the former Yugoslav republics, the greatest increase in participation is in Serbia in 1997, about $46.3 \%$. After Serbia, in the second place is Macedonia, which had the largest share in 1987 (31.8\%). In Bosnia and Herzegovina, the recorded share in 1967 was $21.4 \%$ and the percentage held until 1977 is $20.3 \%$ and the participation of Croatia with $10.7 \%$ in the same year. Montenegro's participation was highest in 1997 (9.5\%). The share in the total number of sheep for Slovenia in the same year is recorded at $0.5 \%$; and had the lowest participation until 2000, when it increased to $2.3 \%$.

If we take the period from 2007-2011 for analysis, since 2007, in some republics, there is a noticeable increase of participation in the joint sum of the total number of sheep $(3,972,450$ heads). In 2007, Serbia still has the largest share of $40.4 \%$, followed by Macedonia with a share of $20.6 \%$, followed by Croatia with $16.3 \%$; then Bosnia and Herzegovina with $13.8 \%$ and at the end with the smallest share in the total number is Montenegro - 5.6\% and Slovenia $3.3 \%$. From 2007 to 2011 , there weren't any major variations in the share percentage, so Serbia still has the largest share in the last year (although slightly less than in 2008 and 2009 (when it was more than 40\%)) and it amounts to 39.3\%. Macedonia in 2010 has a share of $20.9 \%$, followed by Croatia, which has an increased share in 2011 at 17.2\%. Bosnia and Herzegovina has a share of $14 \%$ in 2011, while the lowest participations are those of Montenegro (5.6\%) and Slovenia (3.2\%), which reached the level of participation in 2007. 
Graph 1. Number of sheep in some European countries according to highest number of sheep (in millions of sheep)

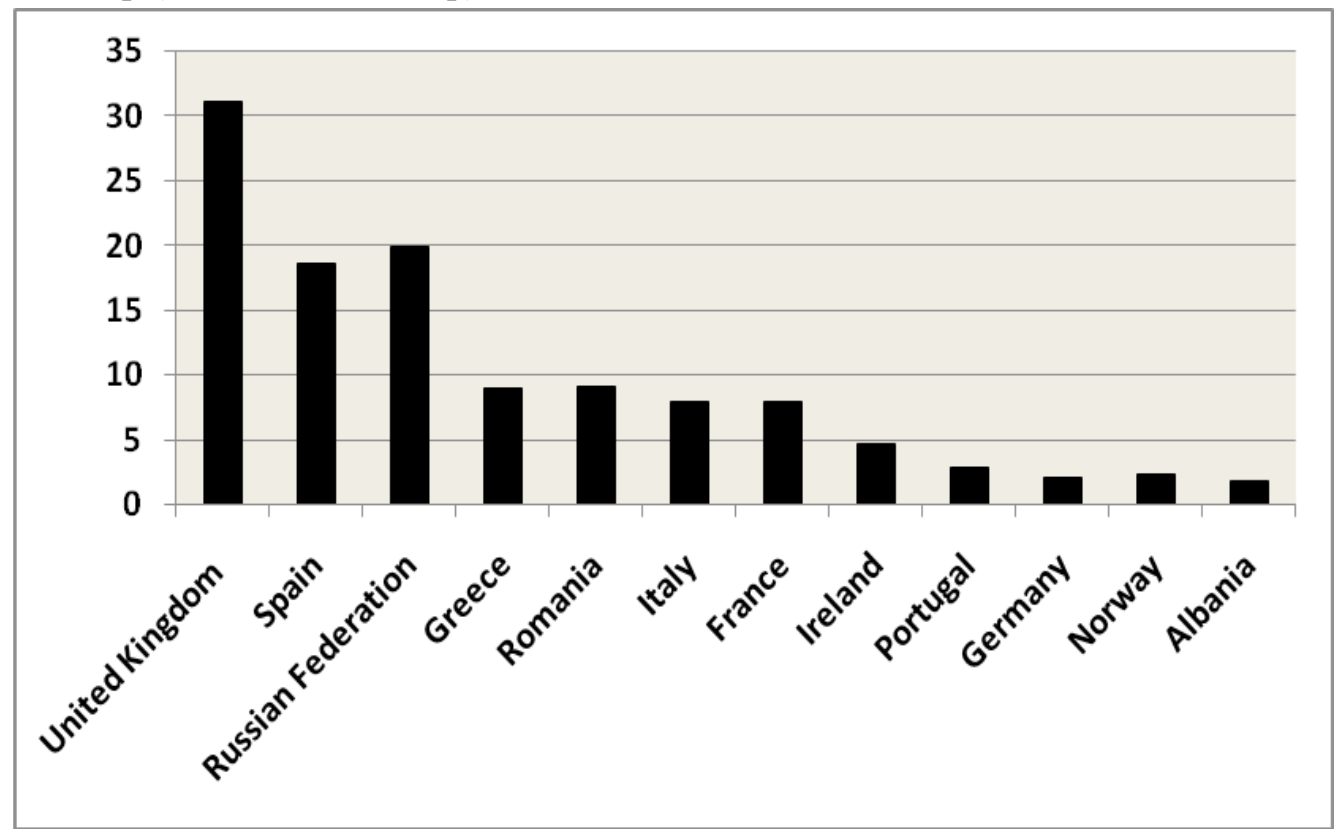

Source: FAO, 2012.

In the world there are around 1,077,762,456 sheep, according to the FAO, most of them in Asia (42.19\%) and Africa (27.75\%); while in Europe approximately $12.13 \%$ of the world's sheep population is being bred (FAO, 2012). The world's largest breeders are China with $12.44 \%$ and Australia with $6.32 \%$. Europe's largest breeders of sheep are the United Kingdom with around 31 million heads, followed by the Russian Federation with over 19 million heads and Spain with more than 18 million heads. The most significant European countries by the number of sheep are shown in the Graph 1.

Out of the total number of sheep in Europe, 130,789,750 heads in twelve countries represent $89.71 \%$ of the European population of sheep (Graph 2.). In the EU, there are $99,862,823$ sheep, which makes up more than $76 \%$ of the total number of sheep that are bred on the European continent. Calculation of the percentage of the total number of 130,790 heads of sheep in Europe, the highest percentage of participation is $23.77 \%$ in the United Kingdom, the Russian Federation with $15.18 \%$ and $14.18 \%$ in Spain.

The total sum of all sheep in all republics is 3,714,442 heads, and their percentage in the total number in Europe is 2.84\%, while the share in the total world production is $0.34 \%$. 
Graph 2. Share of certain countries in total number of sheep in Europe, in 2012 (Number of sheep in Europe $=100 \%$ )

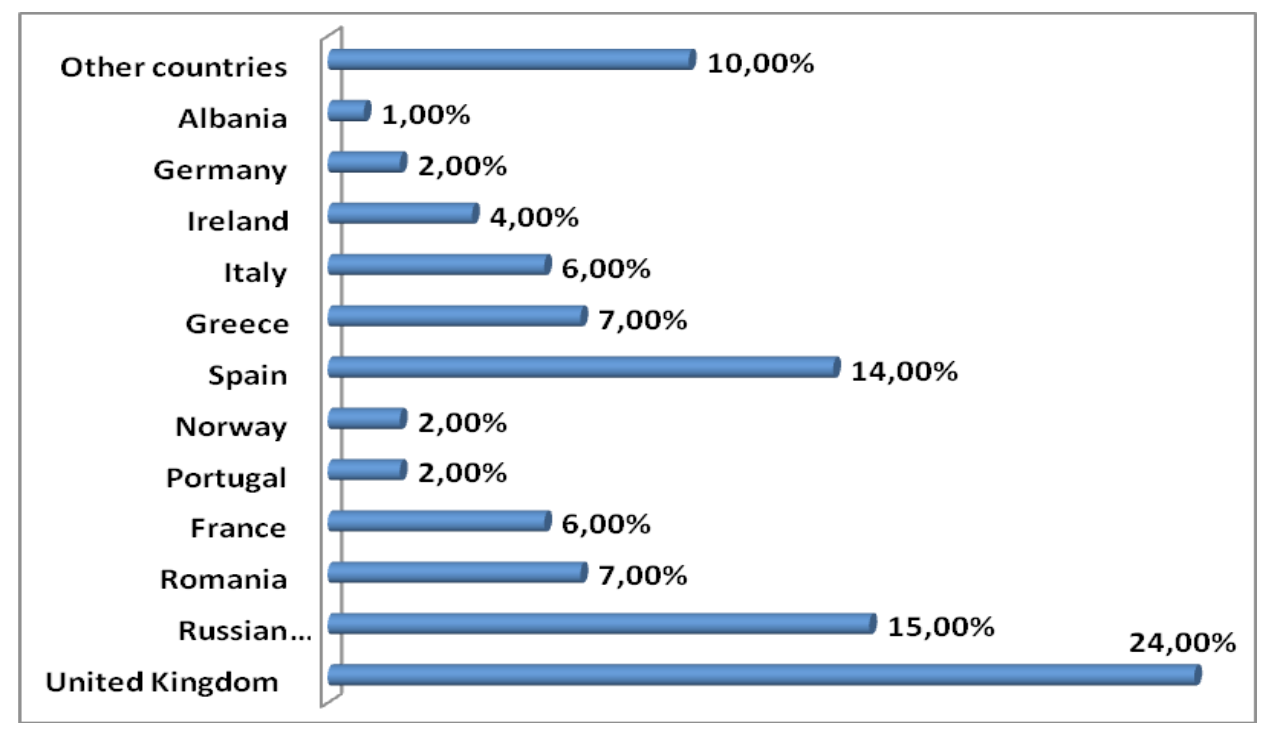

Source: Authors calculation according to FAO, 2012.

According to the analysis of the calculated share percentage in the total number of sheep in all republics with the 3,714,442 heads (2011), Serbia is in the first place with the highest percentage (39.3\%), as well as the percentage share in total number of sheep in Europe (130,789,750 heads) with $1.11 \%$, and the percentage share in world production of sheep $(1,077,762,456$ heads), which is $0.13 \%$. The next is Macedonia with $20.7 \%$ of the total sum, which accounts for $0.59 \%$ of European sheep population, and for $0.071 \%$ in the world. Croatia participates with $17.2 \%$ of the total number, whereas it contributes with $0.48 \%$ in total European sheep population, and $0.059 \%$ in the world's sheep population. Likewise, Bosnia and Herzegovina has a share of $14.0 \%$ in total number, and in the European frame, that participation is at $0.40 \%$ and $0.048 \%$ in the world. The lowest share is in Montenegro with $5.6 \%$ of the total sum, while the share in the total European population of sheep is only $0.16 \%$ and $0.019 \%$ in the world; and Slovenia with $3.2 \%$, and a share of $0.09 \%$ in the European population and $0.011 \%$ in world population.

Based on the calculation of Sredojević and Popović (2014), Serbia during 2012 is on the lowest level concerning its share in the number of sheep in the European Union, Europe and world. In 2012, the share of Serbia slightly increased to $1.68 \%$ compared to 2000 , when the share stood at 1.56\%. However, the share of Serbia in Europe fell from $1.31 \%$ (2000) to $1.27 \%$ (2012) and in the world from $0.18 \%(2000)$ to $0.14 \%(2012)$. It is notable that compared to 2011, the share of Serbia rose slightly by $0.01 \%$ in 2012 .

As for the calculation of sheep number's percentage of participation by the regions the Republic of Serbia, in the observed year of 2011, the highest percentage of participation is in the Region Serbia-South (the Region of Sumadija and the West Serbia, which amounts 
around $60 \%$ ). The reason is the fact that the highest percentage of meadows and pastures in the Republic of Serbia is located in this region, and it amounts to $91.4 \%$. The Region of South and East Serbia follows, with a share of $20.5 \%$; the region of Vojvodina with $16.0 \%$, and finally the Belgrade region with the share of only $3.6 \%$ in the total number of sheep in the Republic of Serbia (Arsić, Jovanović, 2013).

Based on last census from 2012, the highest share in total number of sheep of 1,729,278 heads of sheep in Serbia is in Serbia-South 79.9\%, where the Sumadija Region participates with $60.4 \%$ and Region of South and East Serbia with 19.5\%. Serbia-North participates with $20.1 \%$, where the Belgrade Region belongs, with a share of $4.5 \%$ and Vojvodina Region with $15.6 \%$.

During the 2012 in the Republic of Serbia, out of the total number of sheep - 1,721,036 heads are located in family households (99\%), and only 17,242 heads are in commercial companies and agricultural cooperatives, which is only $1 \%$.

Comparing the total number of sheep in Serbia in 2012 (1,729,278 heads) in relation to the numbers from 2007 and 2008, there is an increase of about $8 \%$ for both years, and compared to 2009 with a $15 \%$ increase, compared to the 2010 increase of $17.2 \%$ and in 2011 we have the largest increase of $18.4 \%$. The average total number of sheep in Serbia for the past six years was 1,563 thousand heads (SORS, 2012).

\section{Number of sheep related to 1,000 inhabitants $/ \mathrm{km}^{2}$ and total agricultural area}

In the paper, besides the percentage change of the total number of sheep, the image of total number of sheep related to 1000 inhabitants per $\mathrm{km}^{2}$ land surface and the total agricultural area, for the past two years for all republics is also done. Results of the calculation in accordance with these parameters are shown in the following text.

When the numerical state of the total number of sheep is brought in relation to the population, for the last two years, we get the data that Macedonia is in the first place (2010) with 378 and (2011) with 372 heads. In relation to the surface $\mathrm{km}^{2}$, it is also the first (2010) with 30.3 and in 2011 with a 29.8 heads. In relation to the agricultural area it comes in second with 69.4 (2010) and 68.4 sheep (2011), (SSORM, 2012).

In the number of sheep in relation to population, the second is Montenegro with 320 heads (2010) and 336 heads (2011). However, in relation to the land area it is on third place with 14.3 (2010) and with 15.1 in 2011. In addition, it's in the fourth place in the number of sheep in relation to the agricultural area of 38.4 in 2010 and 40.5 heads in 2011 (MONSTAT, 2011).

In the number of sheep in relation to population Bosnia and Herzegovina is on the fourth place (2010) with 181 head and on the third place (2011) with 222 heads, related to the land area it comes in as fifth (2010 and 2011) with 10.1 heads. In the number of sheep related to the agricultural land it is on the third place in both observed years with 45.6 heads (FOS, 2011).

As for Serbia, it is third in the number of sheep in relation to the population (in 2010) with 207 and in 2011, Serbia is on fourth place with 205 heads of sheep; compared to the land area 
it is second with 16.7 (2010) and with 16.5 heads in 2011. In relation to the agricultural area it is fifth in both observed years, with 29.2 and 29 heads (SORS, 2014).

If the number of sheep in Croatia is put in relation with the population it comes in fifth with 142 and 144 heads, according to the land area it is the fourth in the observation period with 11.1 and 11.3 heads. However, the number of sheep in Croatia in relation to its agricultural area is in the first place in 2010 and 2011, with 70.2 heads and 71.6 heads, respectively (SBC, 2012a).

The last observed republic is Slovenia, which in its total number of sheep related to all observed parameters, has the least sheep. Related to population it is 63 heads in 2010 and 58 heads in 2011. Related to the land area for 2010 that is 6.4 heads and in 2011 it is 5.9 heads. Finally, related to agricultural land in 2010 it has 26.9 heads, and in 2011, it has 26.2 heads (SURS, 2013).

In the world as well as in Serbia, sheep farming is an important branch of livestock production. Sheep production is primarily regionally distributed in mountainous areas or regions where there is a significant share of pastures in the structure of exploitation of agricultural land. In Serbia, out of 5,051 thousand hectares of agricultural land used in 2011, meadows and pastures constituted $29 \%$. However, due to the intensive process of industrialization in the second half of the twentieth century, there is a trend of depopulation, deagrarisation and demographic emptying of villages resulting in a reduction in the number sheep, and many other mountains and pastures remain empty.

The reduction of the sheep fund (in all republics), in addition to the above reasons, is also influenced by the following factors: unstable economic trends in the country, the lack of long-term policies to improve sheep production, uncertain placement, poor credit standing breeders of sheep, minimal investment of banks and other entities in sheep production, weak links to organizations for processing and marketing sheep products and an increase in the number of elderly households.

In addition, in the period 2004-2008 in the countries of the European Union the number of sheep has declined from 73 million to 68 million heads. However, there are differences between countries, so the number of sheep in Greece remained at almost the same level of 8,980 heads, with minor fluctuations in some years in the period $2006-2010$. In the same period, in Romania there is an increase (in 2006), from 7,678.2 to 8,469.2 heads which is $10.3 \%$ more than in 2007. In 2008 the number grew by about 5\%, and in 2009 , the increase was 3\%, while in 2010 there was a decrease in heads of $8 \%$, but in 2011 there is again an increase in the total number of sheep by $8.6 \%$, reaching the level of heads in 2009 of 9,142 thousand heads of sheep.

In some larger countries of the European Union during the same period (2006-2010), there is notable a decrease of the total number of sheep in countries such as France, Ireland, Italy, Portugal and the UK.

In France in 2006 there were 8,494.2 heads of sheep; in 2007, that number decreased by 
$2.5 \%$; in 2008 by $7 \%$; in 2009 by $2.4 \%$; in 2010 it decreased $8.3 \%$. The trend of increasing the number of sheep is notable in 2011 , when there were 7,977 heads or $15.5 \%$.

In Ireland, the total number of sheep fluctuated in the same period: 2006 saw 3,826.3 heads, in 2007 the decline in the number of sheep was 7.7\%. In 2008, the decrease was at 3\%, in 2009, the decrease was at 7\%, and in 2010 by $2 \%$. In 2011, there was an increase in heads of sheep by $48.7 \%$ compared to the previous year. Compared to 2006 , the increase was as much as $21.3 \%$.

Italy in 2006 had 8,227.2 sheep, while in 2007 it had a slight increase of $1 \%$ compared to the previous year. However, in 2008 a decline in the total number of sheep by $0.8 \%$ was noted, in 2009 , it decreased by $2 \%$, in 2010 it came to $12.5 \%$ compared to the previous year (2009). A percentage increase in the total number can only be seen in 2011 compared to the previous year (14.3\%), which means that it reaches the level of 2009 when there were 8,012.6 sheep.

Portugal during the same period also had a decline in the total number of sheep and in 2006 had 3,549 heads; in 2007, the number of heads decreased by $5.5 \%$, in 2008 by $6.3 \%$, in 2009 by $7.6 \%$, in 2010 there was an evident decrease of $13.6 \%$. In 2011 there is an increase compared to the previous year by $15.7 \%$ thus reaching the level of 2009 when there were 2,905.7 heads.

UK is the country with the largest number of sheep. However, in the same reporting period, a reduction in the total number of sheep occurred, except for 2007 when it had a minimal increase over the previous year (2006, when there were $23,428.5$ heads) by only $1 \%$. In 2008 , there were 21.856 heads and a decrease compared to the previous year was nearly $7.7 \%$. In 2009 it was $2.4 \%$ and in 2010 only $0.2 \%$. In relation to the transitional year 2010 , as in all countries, in 2011 there is an increase in the total number of sheep which amounts to $46.1 \%$ when there were 31.084 heads (SSORM, 2012).

The analysis shows that there is a reduction in the total number of sheep in all countries until 2010, but since 2011, there is an increase because many of the factors that have caused this situation disappeared. One of the biggest causes was the epidemic of foot rot in sheep, which appeared in 2001 in the UK and Ireland, where the number of heads decreased from 20 million to 16 million, or by $25 \%$. In Serbia and the other republics in the observed 2011, there is an increase in Montenegro compared to the previous year by $5.3 \%$ and in Croatia by $1.4 \%$. The greatest decrease in the total number of sheep is in Slovenia (2011) compared to the previous year, and it amounts to $7.7 \%$, followed by Bosnia and Herzegovina at approximately 2.4\%; in Macedonia and Croatia 1.5\% and in Serbia by $1 \%$. However, in Serbia in the census of 2012, compared to the year 2011 there is a maximum increase of $18.4 \%$. According to the mentioned observations, for the year of 2012, the situation in sheep breeding has been improving in Serbia, as well as in other countries. First, it has a strategic significance in hilly-mountain regions, then social significance, because the development of sheep breeding implies young people staying in the rural areas, and ecological significance, due to a great influence to biological resources (Kljajić et al., 2009). 


\section{Conclusion}

From what has been said, it can be concluded that the total number of sheep has been steadily declining in almost all of the republics in the observed period (except for some years in the continuous observed period). In order to overcome the current situation in sheep breeding and job prospects for further development, the measures that could contribute to ensuring the steady and organized growth indicate the economic significance of this production, and higher planned investment in production (supply of breeding rams, reclaiming meadows and pastures, building renovation, etc.). There are also the design of agricultural policy measures in a way that would be stimulating for this production, identifying households that have the conditions and motivations to engage in this type of production and the creation of conditions for sheep breeders to come closer together and become economically stronger.

\section{References}

1. Arsić, S., Kljajić, N., Vuković, P. (2012): Cattle stock and the analysis of total meat production in the Republic of Serbia, Economics of Agriculture, vol. 59, no. 1, pp. 99-114.

2. Arsić, S., Jovanović, M., Vučković, S. (2013): Voluminous (bulky) fodder as a factor of economic improvement sheep production in Serbia, Proceedings, XXVII Conference of Agronomists, Veterinarians, Technologists and Agricultural Economists, vol. 19, no. 3-4, Institut PKB Agroekonomik, Belgrade, pp. 147-157.

3. Arsić S., Jovanović M. (2013): Opportunities for Biomass Production in Meadows and Pastures as Factor of Improving Sheep Production in Serbia, Agro-knowledge, University of Banja Luka, Faculty of Agriculture, vol. 14, no. 2, pp. 297-307.

4. B\&H Federal Office of Statistic (FOS), (2011): Statistical Yearbook of the Republic of Bosnia and Herzegovina, Sarajevo, B\&H, available at: www.fzs.ba

5. Cecić, N.,Vuković, P., Cvijanović, D. (2007): Stanje i mogućnosti unapređenja kozarske i ovčarske proizvodnje u Srbiji, Ekonomika Poljoprivrede, Vol. 54, no. 2, pp. 241-254.

6. Drucker, A. G., Gomez, V., Anderson, S. (2001): The economic valuation of farm animal genetic resources: a survey of available methods, Ecological Economics, vol. 36, pp. 1-18.

7. FAO (2009): Statistical Yearbook 2009, FAO, Rome, available at: www.fao. org/docrep/014/am079m/pdf/am079m00a.pdf

8. FAO (2012): Statistical yearbook, Europe and Central Asia, Food and agriculture, FAO, Rome, available at: www.fao.org/docrep/017/i3138e/i3138e.pdf

9. Federal Statistical Office (FSO), (1968): Statistical yearbook of the Socialist Federal Republic of Yugoslavia, FSO, Belgrade, SFRY. 
10.Federal Statistical Office (FSO), (1978): Statistical yearbook of the Socialist Federal Republic of Yugoslavia, FSO, Belgrade, SFRY.

11. Federal Statistical Office (FSO), (1988): Statistical yearbook of the Socialist Federal Republic of Yugoslavia, FSO, Belgrade, SFRY.

12.Kljajić, N., Arsić, S., Savić, M. (2009.): Analysis of milk production and perspectives of goat and sheep breeding in Serbia, Economics of Agriculture, vol. 56, no. 3, pp. 417-429.

13.Montenegro Statistical Office (MONSTAT), (2011): Statistical yearbook, MONSTAT, Podgorica, Montenegro, available at: www.monstat.org

14. Republic of Macedonia State Statistical Office (SSORM), (2012): Livestock Statistical Yearbook of the Republic of Macedonia 2012, SSORM, Animal Husbandry, Skopje, Macedonia, available at: www.stst.gov.mk

15.Ruane, J. A. (2000): A framework for prioritizing domestic animal breeds for conservation purposes at the national level: a Norwegian case study, Conservation Biology, vol. 14, pp. 1385-1393.

16. Sredojević, Z., Popović, N. (2014): Sheep farming-pastures-sustainability: an economic model of sheep farm for rural areas in Serbia, Thematic Proceedings -International Scientific Conference - Sustainable agriculture and rural development in terms of the Republic of Serbia strategic goals realization within the Danube region - achieving regional competitiveness, June 2014, IAE, Belgrade, pp. 1006-1023.

17. Statistical Bureau Croatia (SBC), (2012a): Statistical Yearbook of Republic of Croatia, SBC, Zagreb, Croatia, available at: www.dzs.hr

18. Statistical Bureau Croatia (SBC), (2012b): Croatia in figures 2011 www.dzs.hr

19. Statistical Office of the Republic of Serbia (SORS), (1998): Statistical yearbook, SORS, Belgrade.

20. Statistical Office of the Republic of Serbia (SORS), (2001): Statistical yearbook, SORS, Belgrade.

21. Statistical Office of the Republic of Serbia (SORS), (2012): Statistical yearbook of Serbia - 2011, SORS, Belgrade.

22. Statistical Office of the Republic of Serbia (SORS), (2012): Census of agriculture, book II, SORS, Belgrade.

23. Statistical Office of the Republic of Serbia (SORS), (2014): Statistical Pocketbook of the Republic of Serbia - 2014, SORS, Belgrade, available at: http://pod2.stat.gov. rs/ObjavljenePublikacije/G2014/pdf/G20142012.pdf

24. Statistical Office of the Republic of Slovenia (SURS), (2013): Statistical Yearbook of Republic of Slovenia, Agriculture and fishing (2007-2011), SURS, Ljubljana, Slovenia, available at: $\underline{w w}$.stst.si

EP 2015 (62) 2 (453-466) 
25. Tempelman, K. A., Cardellino, R. A. (2007): Preserving and developing unique animal genetic resources for future generations, Chapter 6 in: Tempelman, K. A., Cardellino, R. A. (Eds.) - People and animals: traditional livestock keepers: guardians of domestic animal diversity, FAO Inter-Departmental Working Group on Biological Diversity for Food and Agriculture, monograph, FAO, Rome, pp. 111 - 119.

\title{
KOMPARATIVNA ANALIZA BROJA OVACA U BJR I NEKIM EVROPSKIM DRŽAVAMA
}

\section{Slavica Arsićs , Marijana Jovanović ${ }^{6}$, Zorica Sredojevic ${ }^{7}$}

\begin{abstract}
Apstrakt
U Srbiji ovčarstvo iz godine u godinu beleži silazni tok kako po broju ovaca, tako i po proizvodnji mleka i mesa. Glavni cilj ovog rada je analiza broja ovaca u Srbiji i u zemljama u okruženju (BJR).

Upoređujući trenutno stanje ukupnog broja ovaca (2011) sa stanjem u nekadašnjoj Jugoslaviji dolazimo do rezultata koji ukazuju da je u Srbiji za 66\% manje ovaca od ukupnog broja u odnosu na 1967. godinu (bazna godina). Poređenjem sa poslednjim popisu iz 2012. godine u Srbiji je povećan broj ovaca u odnosu na predhodu godinu (2011) za 18.4\%.

Kod ostalih bivših jugoslovenskih republika takođe imamo smanjenje ukupnog broja ovaca: u BiHza 76.5\%, u Crnoj Gori za 64.3\%, Hrvatskoj za 41.3\%, Makedoniji za 63.5\% u odnosu na 1967. godinu (bazna godina), izuzev Slovenije koja ima povećanje ukupnog broja ovaca za 83 hiljade grla.

U radu je dat pregled broja ovaca za neke Evropske države i za pojedine delove sveta, $u$ cilju upoređivanja sa stanjem ovaca $u$ BJR.
\end{abstract}

Ključne reči: ovce, bivše jugoslovenske republike (BJR), Evropa, svet.

5 Mr Slavica Arsić, istraživač-saradnik, Institut za ekonomiku poljoprivrede, Volgina 15, 11060 Beograd, Srbija, Telefon: + 381116972 852, E-mail: slavica a@iep.bg.ac.rs

6 Marijana Jovanović, B.Sc., istraživač-saradnik, Institut za ekonomiku poljoprivrede, Volgina 15, 11060 Beograd, Srbija, Telefon: +381 116972 842, E-mail: marijana_j@iep.bg.ac.rs

7 Prof.drZoricaSredojević, redovniprofesor,UniverzitetuBeogradu,Poljoprivrednifakultet,Institutzaagroekonomiju, Nemanjina 6, 11080Zemun, Srbija, Telefon: +381 11 2615315/lok297,E-mail:zokas@agrif.bg.ac.rs 